\title{
Effect of an intensive mechanical removal effort on a population of non-native rainbow trout Oncorhynchus mykiss in a South African headwater stream
}

\author{
Jeremy Shelton ${ }^{1,2,3}$ | Olaf Weyl ${ }^{4,5}$ | Johannes Van Der Walt ${ }^{6}$ | Sean Marr ${ }^{4}$ | Dean Impson ${ }^{6}$ | \\ Kristine Maciejewski $^{7,8}$ | Donovan Tye ${ }^{7}$ | Helen Dallas ${ }^{3,9}$ | Karen Esler ${ }^{1,2}$
}

${ }^{1}$ Centre for Invasion Biology, Stellenbosch University, South Africa

${ }^{2}$ Department of Conservation Ecology and Entomology, Stellenbosch University, South Africa

${ }^{3}$ Freshwater Research Centre (FRC), Cape Town, South Africa

${ }^{4}$ South African Institute for Aquatic Biodiversity (SAIAB), Grahamstown, South Africa

${ }^{5}$ Centre for Invasion Biology, SAIAB, Grahamstown, South Africa

${ }^{6}$ CapeNature Scientific Services, Stellenbosch, South Africa

${ }^{7}$ Organisation for Tropical Studies, Skukuza, South Africa

${ }^{8}$ Percy FitzPatrick Institute, University of Cape Town, Cape Town, South Africa

${ }^{9}$ Nelson Mandela Metropolitan University, Port Elizabeth, South Africa

Correspondence

Jeremy Shelton, 181 Boyes Drive, Muizenberg, 7945, Cape Town, South Africa.

Email: jembejem@gmail.com

Funding information

National Research Foundation, Grant/Award Number: 77444.

\begin{abstract}
1. Invasions by non-native species can compromise the conservation value of otherwise pristine headwater streams. While both developed and developing countries recognize this threat, few of the latter have suitable budgets to implement control programmes.

2. This study assessed the effectiveness of a mechanical project to remove non-native rainbow trout Oncorhynchus mykiss from a $6 \mathrm{~km}$ section of the upper Krom River, a small headwater stream in the Cederberg Mountains in South Africa's Cape Floristic Region (CFR).

3. From October 2013 to February 2014, 354 O. mykiss were removed by angling (58\%), fyke netting (28\%) and gill netting (14\%). This resulted in a marked reduction, but not eradication, of the 0 . mykiss population (fish relative abundance decreased from $0.53 \pm 0.09$ fish per net per night in October 2013 to $0.21 \pm 0.09$ fish per net per night in February 2014). Following the cessation of manual removals, the relative abundance of 0 . mykiss had increased to $0.56 \pm 0.18$ fish per net per night by March 2016, suggesting that without sustained removal effort, the population will rapidly return to its pre-removal abundance level.

4. Further work is needed to refine the methodology and test the effectiveness of mechanical removal of non-native freshwater fish in a variety of ecological settings in the CFR. This approach holds potential for meeting the dual goals of reducing the ecological impacts of non-native fishes and generating employment opportunities in line with the policy objectives of developing nations.
\end{abstract}

\section{KEYWORDS}

alien species, fish, mechanical removal, restoration, river, stream

\section{1 | INTRODUCTION}

Headwater streams are critical habitats for conserving freshwater biodiversity (Clarke, Mac Nally, Bond, \& Lake, 2008), but invasions by non-native predatory fish can compromise the value of otherwise pristine headwater habitats as sanctuaries for native species within largely transformed riverscapes (Lepori, Benjamin, Fausch, \& Baxter, 2012; Shelton, Clark, Sephaka, \& Turpie, 2017). While both developed and developing countries recognize this threat, few of the latter have implemented control programmes to manage it (Pino-Del-Carpio, Miranda, \& Puig, 2010). In South Africa's Cape Floristic Region (CFR), introduced predatory fish such as rainbow trout Oncorhynchus mykiss and smallmouth bass Micropterus dolomieu have depleted, or eliminated, native endemic fish populations, modified community structure in otherwise pristine headwater streams, and pose arguably the greatest future threat to several of the region's native fish species (Ellender \& Weyl, 2014). Bass (Micropterus spp.) typically invade and become established in the foothill reaches of streams, and generally do not co-exist with native fish species in the CFR (Ellender \& Weyl, 2014; Wan Der Walt, Weyl, Woodford, \& Radloff, 2016; Woodford, Impson, Day, \& Bills, 2005). Trout, on the other hand, generally colonize cooler headwater reaches upstream of, but sometimes 
overlapping with, bass distributions and their impact on native fish populations appears to be density-dependent (Shelton, Samways, \& Day, 2014).

In certain situations, the removal of alien fishes can be an effective means for rehabilitating invaded rivers through increasing habitat area and connectivity for threatened and fragmented native fish populations. A recent project undertaken in the Rondegat River, a small headwater stream in the Olifants-Doorn River system (CFR), demonstrated that non-native $M$. dolomieu can effectively be removed from a section of stream using the piscicide rotenone, with clear benefits for the native biota (Weyl, Finlayson, Impson, Woodford, \& Steinkjer, 2014). While effective, the undesirable impacts that chemical interventions can have on non-target organisms (Vinson, Dinger, \& Vinson, 2010) are a cause of concern for implementers (Dalu, Wasserman, Jordaan, Froneman, \& Weyl, 2015) and often a focus area for groups lobbying against alien fish removals (Ellender et al., 2014). As a result, mechanical approaches, such as netting, angling and electrofishing, are often applied in situations where the collateral damage associated with chemical removal is considered undesirable (Halfyard, 2010; Knapp \& Matthews, 1998). Mechanical removal efforts in other parts of the world have produced mixed results. In general, considerable effort has been required to measurably deplete non-native fish populations using mechanical methods (Knapp, Boiano, \& Vredenburg, 2007), but in other cases mechanical approaches have proved more effective (Franssen, Davis, Ryden, \& Gido, 2014; Propst et al., 2015), sometimes even resulting in complete eradication (Shepard, Nelson, Taper, \& Zale, 2014). Mechanical removal efforts also generally require more manpower and longer-term commitment than chemical treatments (Finlayson et al., 2000; Halfyard, 2010). Thus, employment generation, a common priority in developing countries, may be an added advantage of the mechanical approach.

In the Krom River, a headwater tributary of the Olifants-Doorn River system, the provincial conservation authority, CapeNature, intends to restore native fish habitat by eradicating non-native $O$. mykiss and introducing threatened native fish species that are likely to have occurred in the river before non-native fish introduction. The Krom River was one of four rivers originally selected for the Cape Action for People and the Environment (CAPE) river rehabilitation project, which involved non-native fish eradication to conserve more effectively threatened native fish species (Marr, Impson, \& Tweddle, 2012). An environmental impact assessment undertaken by Enviro-Fish Africa (2009) to evaluate this proposal found that rotenone treatment could have adverse effects on non-target aquatic biota in the Krom River, and therefore recommended that mechanical removal be tested as an alternative to chemical treatment. As a result, CapeNature carried out a trout removal programme from October 2013 to February 2014, using a contract staff team that fished the upper Krom River intensively using angling, fyke and gill nets. The aim of this programme was to eliminate O. mykiss from the upper Krom River. This paper reports the numbers and size ranges of $O$. mykiss removed using different mechanical methods, and evaluates changes in abundance of the O. mykiss population in the upper Krom River following mechanical removal.

\section{2 | METHODS}

\section{1 | Study area}

The Krom River rises in the Cederberg Mountains at an elevation of $\sim 1500 \mathrm{~m}$ and flows in an easterly direction for approximately $15 \mathrm{~km}$ before joining the Matjies River which then flows into the Doring River (Figure 1). The upper river has a narrow (generally $<5 \mathrm{~m}$ wide), shallow (generally $<1 \mathrm{~m}$ deep) wetted channel and comprises pools, chutes and bedrock steps interspersed by occasional cobble-bed riffles. The area has a Mediterranean climate with warm, dry summers and cold, wet winters (Cowling \& Holmes, 1992), and the upper catchment is characterized by quartzitic Table Mountain Sandstones (Tankard et al., 1982) and near-pristine Cederberg Sandstone Fynbos (a low-growing sclerophyllous scrub characteristic of the mountains of the CFR; Mucina \& Rutherford, 2006).

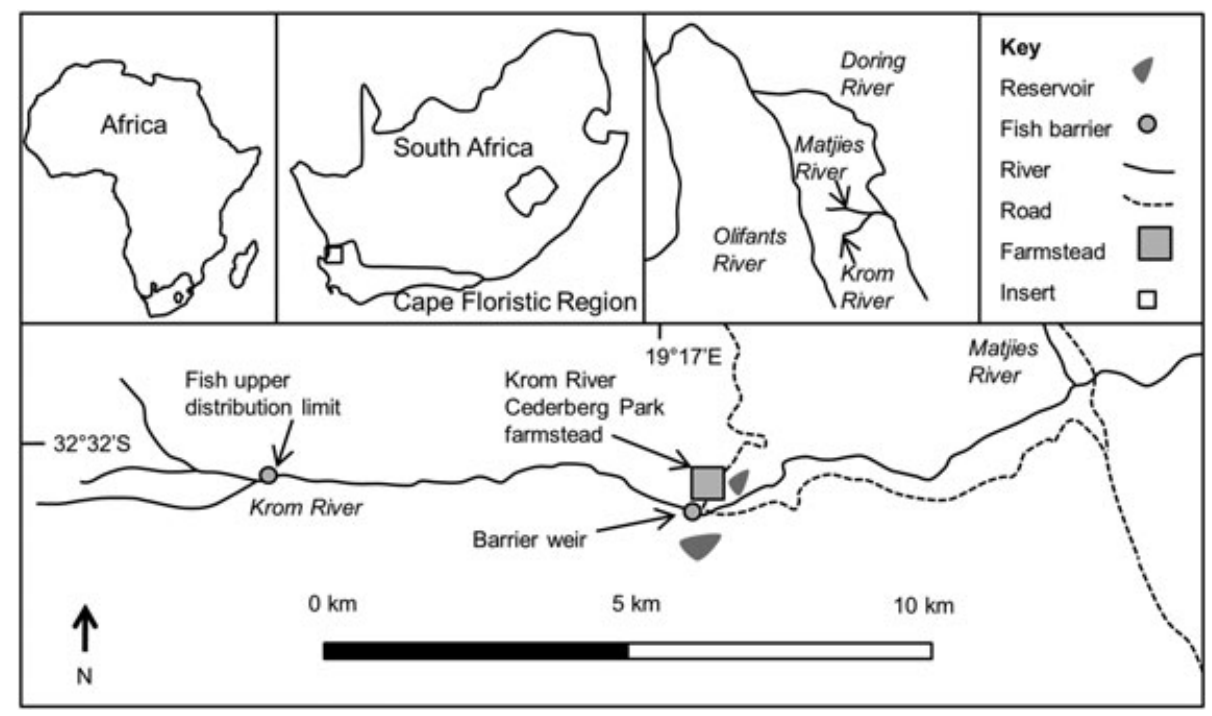

FIGURE 1 Location of the upper Krom River in the Cederberg Mountains of the Cape Floristic Region of South Africa. The Krom River flows into the Matjies River, which in turn feeds into the Doring River mainstem. All sampling took place along the $6 \mathrm{~km}$ section of river between the barrier weir at the Krom River Park farmstead and the fish upper distribution limit 
A small waterfall marks the upper limit of the fish-supporting section of the Krom River, and the $6 \mathrm{~km}$ of river down to the Krom River farmstead is largely unaffected by human impacts (Marr et al., 2012). A fish barrier ( $\mathrm{a} \sim 2 \mathrm{~m}$ vertical concrete weir obstructing upstream movement, funded by Kromrivier Cederberg Park) was constructed at the farmstead in 2013 to prevent recolonization of alien fish following their anticipated removal by CapeNature between the concrete weir barrier and the upstream waterfall. Non-native O. mykiss largemouth bass $M$. salmoides and the native Clanwilliam rock catlet Austroglanis gilli are present upstream and downstream of the barrier, while the Endangered sawfin 'Pseudobarbus' serra and non-native bluegill Lepomis macrochirus occur downstream of the barrier only (Marr et al., 2012). There have been no records of any other indigenous fish in the proposed treatment section of the Krom River (J Van der Walt, unpubl. Data).

\section{2 | Oncorhynchus mykiss removal and population surveys}

Oncorhynchus mykiss were removed from the upper Krom River by the CapeNature contract team, using a combination of angling, fyke nets and gill nets (mesh size $25-50 \mathrm{~mm}$ ) conducted over 33 days of fishing between October 2013 and February 2014. Electrofishing has proved effective at reducing the abundance of O. mykiss elsewhere (Propst et al., 2015), but was not used in the upper Krom River because of the low conductivity of the water $\left(<20 \mu \mathrm{S} \mathrm{cm}^{-1}\right)$. Oncorhynchus mykiss populations above the barrier weir were surveyed using fyke nets 8 years before (three surveys in 2005-2006) and immediately after (two surveys in 2015-2016) the O. mykiss removal programme. In addition, fyke net catches made by CapeNature during the removal programme provided estimates of the relative abundance of O. mykiss on five occasions between 2013 and 2014. The methods used in the surveys are described in detail in Marr et al. (2012). In summary, fyke nets (basal diameter $600-800 \mathrm{~mm}$, mesh size 2-4 mm) were set overnight at randomly selected sites along the $6 \mathrm{~km}$ section of river, checked the following morning, and all 0 . mykiss captured were measured (nearest $\mathrm{mm}$ fork length, $\mathrm{FL}$ ) and released back to the stream unharmed, except for fish captured during the removal period, which were not returned to the river. The number of nets set during each survey was determined by the availability of nets, time and manpower, and ranged between three and 15.

\section{3 | Data analysis}

Estimates of catch per unit effort (CPUE; mean \pm SE fish per net per night) for O. mykiss were computed for the three surveys conducted before the removal programme (December 2005 to October 2006), the two surveys after the removal programme (October 2013 and February 2014), and for the fyke net catch data collected during each of the 5 months over which the removal programme was conducted (March 2015 to March 2016). Oncorhynchus mykiss abundance estimates were compared using Kruskal-Wallis analysis since the data did not meet the assumptions of parametric analysis, even after transformation. The relationship between $O$. mykiss CPUE and cumulative 0 . mykiss removed was assessed using linear regression.
Length-frequency distributions were compiled to examine differences in size selectivity by the different removal methods.

\section{3 | RESULTS}

Oncorhynchus mykiss CPUE (mean $\pm \mathrm{SE}$ ) ranged from a maximum of $4.43 \pm 0.98$ fish per net per night in December 2005 to a minimum of $0.10 \pm 0.09$ fish per net per night in January 2014 (Figure 2(a)). At the onset of the fish removal programme in October 2013, O. mykiss CPUE was $0.53 \pm 0.09$ fish per net per night, and by February 2014 this value had decreased to $0.21 \pm 0.09$ fish per net per night. Following the cessation of manual removals, CPUE increased to $0.56 \pm 0.18$ fish per net per night by March 2016. Kruskal-Wallis analysis revealed a significant difference in fyke net CPUE among the different sampling visits (Figure $3 ; H_{9}=35.82, P<0.001$ ).

Initially, the Cape Piscatorial Society (CPS, a local fly fishing club), removed 47 O. mykiss (6-9 October 2013), and subsequently (8 October 2013 to 24 February 2014) 307 O. mykiss were removed by the CapeNature team. CapeNature took the decision to stop the removal programme in February 2014, after just one summer, owing to difficulties associated with capturing small (<100 mm) O. mykiss size-classes. Oncorhynchus mykiss harvest was highest in October 2013 ( $n=124$ ), but decreased steadily to $n=18$ in February 2014 (Figure 2(b)). Overall, the majority of fish (58\%) were removed by

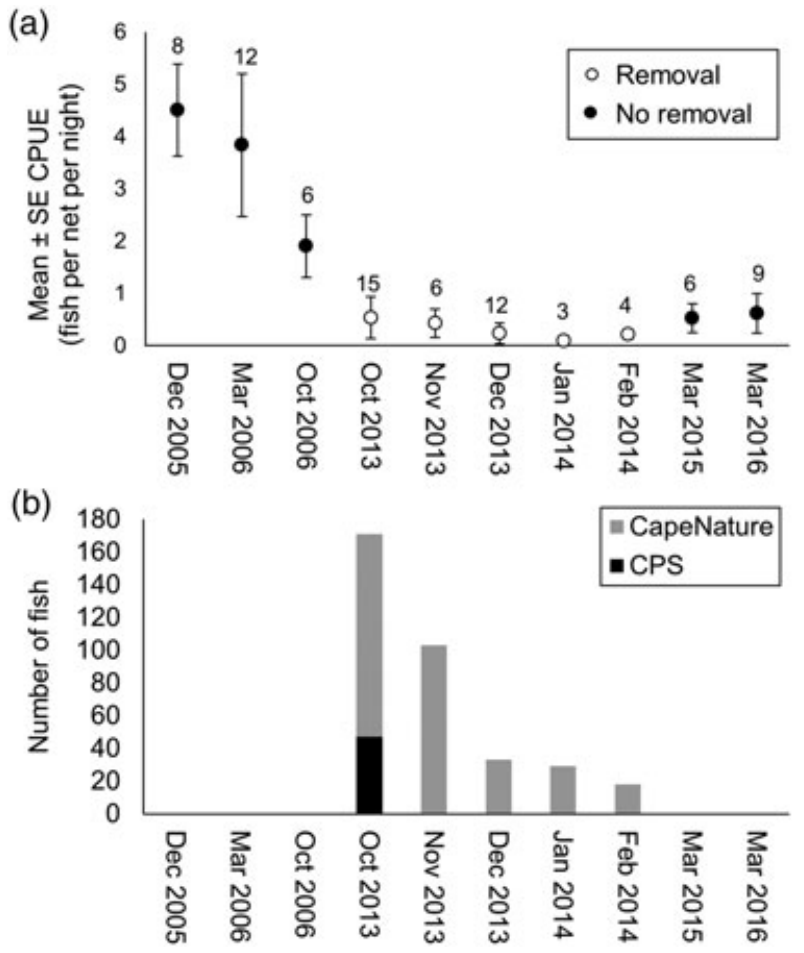

FIGURE 2 (a) Mean \pm SE fyke net catch per unit effort (CPUE; fish per net per night) for Oncorhynchus mykiss over the study period. Black data points represent catch data collected before and after the removal programme, while white data points represent 0 . mykiss catches as part of the removal programme. Numbers above data points indicate sample sizes (number of fyke nets set) for each sampling period. (b) Total numbers of $O$. mykiss removed during summer 2013/14 by the Cape Piscatorial Society (black bar) and CapeNature (grey bars) 


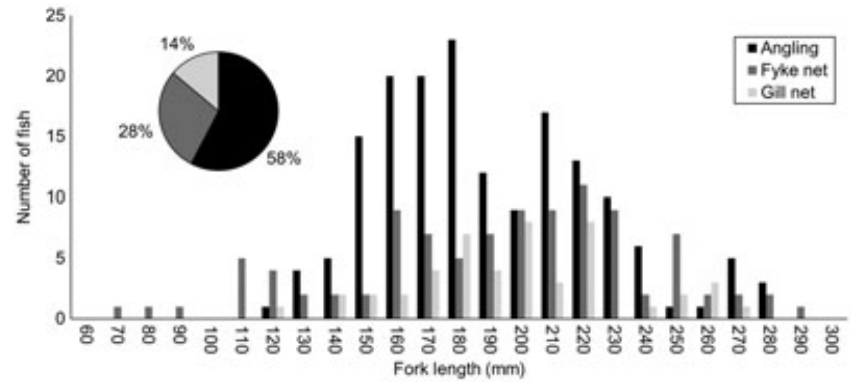

FIGURE 3 Length-frequency distributions of Oncorhynchus mykiss removed from the Krom River between October 2013 and February 2014 using angling (black), fyke nets (dark grey) and gill nets (light grey). The pie chart shows the percentage catch of each removal method

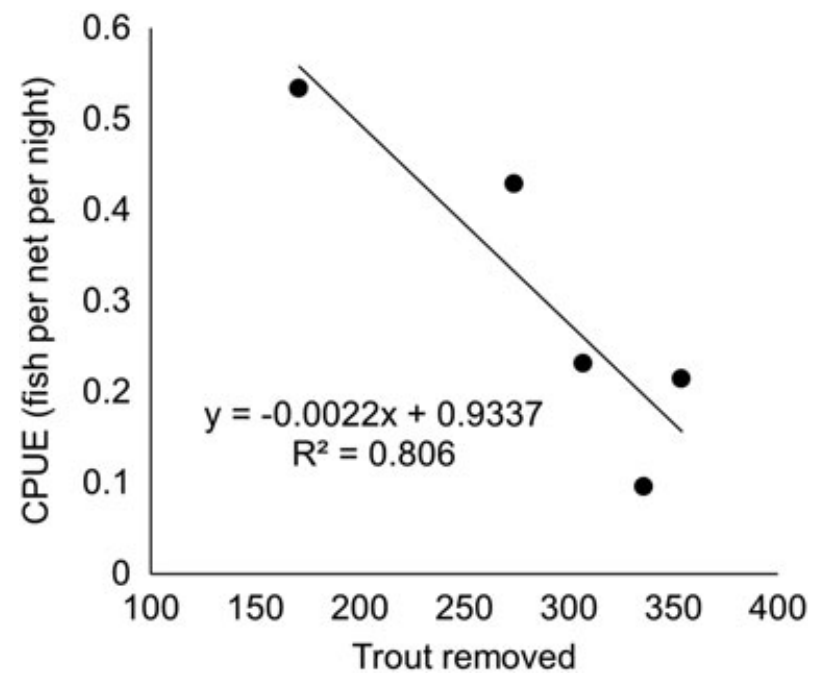

FIGURE 4 Linear relationship between mean catch per unit effort (CPUE, fish per net per night) of Oncorhynchus mykiss and the cumulative number of $O$. mykiss removed during the removal programme between October 2013 and February 2014

angling, 28\% using fyke nets and 14\% with gill nets; there was some evidence of gear selectivity, in that fyke net catches included some fish that were smaller ( $<120 \mathrm{~mm}$ ) than those collected by angling and gill netting (Figure 3). Fyke net CPUE was negatively correlated with the cumulative number of fish removed (Figure 4).

\section{4 | DISCUSSION}

Globally, efforts to remove non-native freshwater fishes using mechanical methods have produced mixed results (Franssen et al., 2014; Halfyard, 2010; Propst et al., 2015), and no successful mechanical eradication has yet been documented for South African rivers. The removal effort reported here led to a marked reduction in O. mykiss CPUE within a $6 \mathrm{~km}$ section of the upper Krom River, but the species was not eradicated because of gear selectivity and budgetary constraints. The relatively rapid increase in O. mykiss CPUE after the cessation of manual removals indicates that without sustained removal effort, the population returned to near its pre-removal abundance level within 2 years. The total cost of the project was approximately
R150 000 ( US $\$ 10$ 600) which covered salaries, transport and equipment for 40 days. This equates to approximately R3,750 ( US\$260) per day of mechanical removal - roughly $10 \%$ of the daily expenditure of a similar recent mechanical removal project undertaken in the USA (Propst et al., 2015).

While mechanical removal techniques generally receive higher levels of public support than chemical removal methods, they also have some important limitations. The success of mechanical removal can be influenced by habitat complexity, gear choice, species or size-classspecific responses to treatment, and budgetary constraints (Propst et al., 2015; Shepard et al., 2014). The effectiveness of mechanical removal techniques is density-dependent, and declines rapidly as target organism densities tend toward zero (Bomford \& Tilzey, 1997). Achieving complete eradication is challenging because of the high cost and labour effort required to capture every individual, particularly small size-classes as was the case in the present study (Finlayson et al., 2000). Moreover, the benefits of reducing the density of a non-native species will remain in the short term unless the removal effort is sustained (Finlayson et al., 2000).

Despite these challenges, successful eradications (Shepard et al., 2014) and sustained population reductions (Propst et al., 2015) with resultant benefits for native fishes have been achieved in developed countries (particularly in the USA) where such endeavours are nationally supported and funded. On the other hand, in developing countries such as South Africa, where unemployment is commonly a significant policy issue, projects concerned with removing non-native species are more likely to receive government support if they promote job creation (Van Wilgen, Le Maitre, \& Cowling, 1998; Woodford et al., 2016). Given that the success of mechanical efforts to remove non-native fish from stream reaches is directly determined by available manpower and long-term commitment, there may be scope to effectively combine such efforts with creating employment opportunities in the same way that the successful 'Working for Water' alien plant clearing initiative has created substantial employment opportunity in South Africa (Van Wilgen et al., 1998).

Although unsuccessful at completely eradicating O. mykiss, the data here show that mechanical methods were effective at reducing their abundance. This could be highly beneficial for native species in rivers where there is co-existence with non-native species rendering the use of piscicides inappropriate (Shepard et al., 2014). Indeed, Shelton et al. (2014) showed that the predatory impact of O. mykiss on small-bodied CFR native fishes was density-dependent in that the natives were able to co-exist with 0 . mykiss where their density was $<3$ fish per $100 \mathrm{~m}^{2}$. In future, such projects should consider whether mechanical methods can be used to completely eradicate non-native fishes from CFR headwater streams, and under what circumstances and environmental conditions mechanical removal will be most effective. Where mechanical methods are practicable, employment opportunities generated through their use could be used to obtain government support in developing countries.

\section{ACKNOWLEDGEMENTS}

Kromrivier Cederberg Park is thanked for accommodation and access to sampling sites and its ongoing support for fish conservation efforts. Stellenbosch University is thanked by JM Shelton for Subcommittee B 
funding. CapeNature thanks the Department of Environmental Affairs for funding the eradication effort, and $\mathrm{K}$ Menck for leading the eradication contract team. The National Research Foundation (NRF Grant No. 77444) is thanked by Olaf LF Weyl for its continued support. The Centre of Excellence in Invasion Biology and CAPE GEF Project are thanked for providing the funding for SM Marr to conduct the fish surveys in 2005-2006. K Maciejewski and D Tye thank the OTS South

Africa for field costs.

\section{REFERENCES}

Bomford, M., \& Tilzey, R. (1997). Pest management principles for European carp. In J. Roberts, \& R. Tilzey (Eds.), Controlling carp: Exploring options for Australia. Proceedings of a workshop 22-24 October 1996, Albury. (pp. 9-20 ).CSIRO and Murray-Darling Basin Commission.

Clarke, A., Mac Nally, R., Bond, N., \& Lake, P. S. (2008). Macroinvertebrate diversity in headwater streams: A review. Freshwater Biology, 53, 1707-1731.

Cowling, R. M., \& Holmes, P. M. (1992). Flora and vegetation. In R. M. Cowling (Ed.), The ecology of fynbos: Nutrients, fire and diversity) (pp. 23-61). Cape Town: Oxford University Press.

Dalu, T., Wasserman, R. J., Jordaan, M. J., Froneman, W. P., \& Weyl, O. L. F. (2015). An assessment of the effect of rotenone on selected non-target aquatic fauna. PloS One, 10, e0142140. doi:10.1371/journal. pone. 0142140

Ellender, B. R., \& Weyl, O. L. F. (2014). A review of current knowledge, risk and ecological impacts associated with non-native freshwater fish introductions in South Africa. Aquatic Invasions, 9, 117-132.

Ellender, B. R., Woodford, D. J., Weyl, O. L. F., \& Cowxl, I. G. (2014). Managing conflicts arising from fisheries enhancements based on non-native fishes in southern Africa. Journal of Fish Biology, 85, 1890-1906.

Enviro-Fish Africa. (2009). Environmental impact assessment of the proposed eradication of invasive alien fishes from four river sections in the Cape Floristic Region. Enviro-Fish Africa (Pty) Ltd: Grahamstown.

Finlayson, B. J., Schnick, R. A., Cailteux, R. L., DeMong, L., Horton, W. D., McClay, W., ... Tichacek, G. J. (2000). Rotenone use in fisheries management: Administrative and technical guidelines manual. Bethesda, MD: American Fisheries Society.

Franssen, N. R., Davis, J. E., Ryden, D. W., \& Gido, K. B. (2014). Fish community responses to mechanical removal of nonnative fishes in a large southwestern river. Fisheries, 39, 352-363.

Halfyard, E. (2010). A review of options for the containment, control and eradication of illegally introduced smallmouth bass (Micropterus dolomieu). Canadian Technical Report of Fisheries and Aquatic Sciences 2865. Moncton, New Brunswick: Government of Canada Publications.

Knapp, R. A., Boiano, D. M., \& Vredenburg, V. T. (2007). Removal of nonnative fish results in population expansion of a declining amphibian (mountain yellow-legged frog, Rana muscosa). Biological Conservation, 135, 11-20.

Knapp, R. A., \& Matthews, K. R. (1998). Eradication of nonnative fish by gill netting from a small mountain lake in California. Restoration Ecology, 6, 207-213.

Lepori, F., Benjamin, J. R., Fausch, K. D., \& Baxter, C. V. (2012). Are invasive and native trout functionally equivalent predators? Results and lessons from a field experiment. Aquatic Conservation: Marine and Freshwater Ecosystems, 22, 787-798.

Marr, S. M., Impson, N. D., \& Tweddle, D. (2012). An assessment of a proposal to eradicate non-native fish from priority rivers in the Cape
Floristic Region, South Africa. African Journal of Aquatic Science, 37, 131-142.

Mucina, L., \& Rutherford, M. C. (Eds) (2006). The vegetation of South Africa, Lesotho and Swaziland. Strelitzia 19. Pretoria, South Africa: South African National Biodiversity Institute.

Pino-Del-Carpio, A., Miranda, R., \& Puig, J. (2010). Non-native freshwater fish management in biosphere reserves. Management of Biological Invasions, 1, 13-33.

Propst, D. L., Gido, K. B., Whitney, J. E., Gilbert, E. I., Pilger, T. J., Monié, A M., ... Myers, D. M. (2015). Efficacy of mechanically removing nonnative predators from a desert stream. River Research and Applications, 31, 692-703.

Shelton, J. M., Clark, B. M., Sephaka, T., \& Turpie, J. K. (2017). Population crash in Lesotho's endemic Maloti minnow Pseudobarbus quathlambae following invasion by translocated smallmouth yellowfish Labeobarbus aeneus. Aquatic Conservation: Marine and Freshwater Ecosystems, 27, 65-77

Shelton, J. M., Samways, M. J., \& Day, J. A. (2014). Predatory impact of nonnative rainbow trout on endemic fish populations in headwater streams in the Cape Floristic Region of South Africa. Biological Invasions, 17, 365-369.

Shepard, B. B., Nelson, L. M., Taper, M. L., \& Zale, A. V. (2014). Factors influencing successful eradication of nonnative Brook Trout from four small Rocky Mountain streams using electrofishing. North American Journal of Fisheries Management, 34, 988-997.

Tankard, A. J., Jackson, M. P. A., Eriksson, K. A., Hobday, D. K., Hunter, W. E. L., \& Minter, D. R. (Eds) (1982). Crustal evolution of Southern Africa: 3.8 billion years of earth history (pp. 333-363). New York: Springer.

Van Der Walt, J. A., Weyl, O. L. F., Woodford, D. J., \& Radloff, F. G. T. (2016). Spatial extent and consequences of black bass (Micropterus spp.) invasion in a Cape Floristic Region river basin. Aquatic Conservation: Marine and Freshwater Ecosystems, 26, 736-748.

Van Wilgen, B. W., Le Maitre, D. C., \& Cowling, R. M. (1998). Ecosystem services, efficiency, sustainability and equity: South Africa's Working for Water Programme. Trends in Ecology \& Evolution, 13, 378.

Vinson, M. R., Dinger, E. C., \& Vinson, D. K. (2010). Piscicides and invertebrates: After 70 years, does anyone really know? Fisheries, 35, 61-71.

Weyl, O. L. F., Finlayson, B., Impson, N. D., Woodford, D. J., \& Steinkjer, J. (2014). Threatened endemic fishes in South Africa's Cape Floristic Region: A new beginning for the Rondegat River. Fisheries, 39, 270-279

Woodford, D. J., Impson, N. D., Day, J. A., \& Bills, I. R. (2005). The predatory impact of invasive alien smallmouth bass, Micropterus dolomieu, on indigenous fishes in a Cape Floristic Region mountain stream. African Journal of Aquatic Science, 30, 167-173.

Woodford, D. J., Richardson, D. M., Maclsaac, H. J., Mandrak, N. E., van Wilgen, B. W., Wilson, J. R. U., \& Weyl, O. L. F. (2016). Confronting the wicked problem of managing biological invasions. NeoBiota, 31, 63-86.

How to cite this article: Shelton J, Weyl O, Van Der Walt J, et al. Effect of an intensive mechanical removal effort on a population of non-native rainbow trout Oncorhynchus mykiss in a South African headwater stream. Aquatic Conserv: Mar Freshw Ecosyst. 2017;00:1-5. https://doi.org/10.1002/ aqc. 2752 